\title{
HUBUNGAN PEMBERIAN ASUPAN MAKANAN PENDAMPING ASI (MPASI) DENGAN PERTUMBUHAN BAYI/ANAK USIA 6-24 BULAN
}

\author{
Alfie Ardiana Sari ${ }^{1}$, Ratih Kumorojati ${ }^{2}$ \\ Universitas Jenderal Achmad Yani Yogyakarta Fakultas Kesehatan
}

\begin{abstract}
Background: The first two years of life is a period that lasts very short and cannot be repeated again, so it is referred to as a "golden period" or a window of opportunity. Inappropriate nutritional intake will also cause children to experience malnutrition, which ultimately increases the incidence of morbidity and mortality. According to a survey of micronutrients in 12 provinces in Indonesia shows that the age group 6-11 months consume nutrients lower than other age group. Purpose of this research is the relationship of Complementary Food Intake of Breast Milk (MPASI) with infants / children growth ages 6-24 months. Methods: This study was a descriptive analytic study with a cross-sectional approach. The population is mothers who have babies / children aged 6-24 months. Samples were taken by consecutive sampling method with 18 babies / children. Data analysis using Chi Square with a significance limit of $\alpha=$ 0.05. Result: Respondents with Complementary Food Intake of Breast Milk giving, most of the growth was normal, namely 10 respondents (55.5\%), respondents with sufficient Complementary Food Intake of Breast Milk giving, normal growth was 2 respondents (11.1\%) and respondents with less Complementary Food Intake of Breast Milk giving were high growth $(11.1 \%)$. Conclusion: There was no significant relationship between the provision of complementary feeding and the growth of infants / children 6-24 months in the Gamping Wirastri Integrated Health Center in Sleman.
\end{abstract}

Keywords: Complementary Food Intake of Breast Milk (MPASI; Growth;Baby/Children).

\section{PENDAHULUAN}

Pertumbuhan merupakan salah satu indikator terbaik untuk melihat status gizi dan kesehatan anak. Masa dua tahun pertama kehidupan merupakan masa yang sangat peka terhadap lingkungan dan masa ini berlangsung sangat singkat serta tidak dapat diulang lagi, sehingga masa baduta (bawah dua tahun) disebut sebagai "masa emas" atau window of opportunity atau masa kritis.

Status gizi balita merupakan hal penting yang harus diketahui oleh setiap orang tua. Ketidaktahuan tentang cara pemberian makanan bayi dan anak, dan adanya kebiasaan yang merugikan kesehatan, secara langsung dan tidak langsung menjadi penyebab utama terjadinya masalah kurang gizi dan infeksi pada anak, khususnya pada umur dibawah dua tahun. Kurang gizi pada balita dapat berdampak terhadap pertumbuhan fisik maupun mentalnya. Anak kelihatan pendek dan kurus dibandingkan temanteman sebayanya yang lebih sehat, ketika memasuki usia sekolah tidak bisa berprestasi menonjol karena kecerdasannya terganggu.

Masalah gizi umumnya disebabkan oleh dua faktor, faktor yang pertama yakni 
faktor langsung yang berhubungan dengan asupan gizi atau konsumsi makanan terhadap zat gizi tertentu dan penyakit infeksi. Faktor yang kedua adalah faktor tidak langsung berupa pengetahuan ibu tentang makanan bergizi, pendidikan orangtua, pendapatan dalam keluarga.

Faktor langsung dari asupan gizi adalah Air Susu Ibu (ASI) dan Makanan Pendamping Air Susu Ibu (MP-ASI). Makanan Pendamping ASI adalah makanan atau minuman yang mengandung zat gizi dan diberikan kepada bayi atau anak usia 6-24 bulan guna memenuhi kebutuhan gizi selain dari ASI. Pemberian MP-ASI berarti memberikan makanan lain sebagai pendamping ASI yang diberikan pada bayi atau anak mulai usia 6-24 bulan. Pemberian MP-ASI berarti memberikan makanan lain sebagai pendamping ASI yang diberikan pada bayi dan anak usia 624 bulan. Pemberian ASI secara eksklusif selama enam bulan pertama dan MP-ASI yang tepat merupakan upaya meningkatkan kelangsungan hidup anak, sedangkan ASI eksklusif yang diberikan terlalu lama akan menunda pemberian MP-ASI. Akibatnya anak akan menerima asupan zat gizi yang tidak adekuat untuk menunjang proses pertumbuhan dan perkembangan.

MP-ASI yang baik adalah memenuhi persyaratan tepat waktu, bergizi lengkap, cukup dan seimbang, aman, dan diberikan dengan cara yang benar. MP-ASI pertama yang umum diberikan pada bayi di Indonesia adalah pisang dan tepung beras yang dicampur ASI. Anak yang mengalami defisiensi asupan protein pada masa seribu hari pertama kehidupan dan berlangsung lama meskipun asupan energinya tercukupi akan mengalami hambatan pada proses pertumbuhan tinggi badan.

Menurut survei mikronutrien di 12 provinsi di Indonesia menunjukkan bahwa kelompok usia 6-11 bulan mengonsumsi zat gizi lebih rendah dibandingkan dengan kelompok usia lainnya. Penelitian yang dilakukan oleh Imtihanatun dkk. (2013) menyebutkan bahwa balita yang mendapatkan MP-ASI tidak sesuai memiliki risiko 7,4 kali mengalami stunting dibandingkan balita yang mendapatkan MP-ASI sesuai. Berdasarkan uraian masalah tersebut, penting untuk dilakukan penelitian untuk mengetahui hubungan asupan makanan dengan pertumbuhan pada bayi/anak usia 6-24 bulan yang dilakukan melalui kegiatan posyandu. Salah satu posyandu di Dukuh Gamping Tengah adalah Posyandu Wirastri dengan jumlah bayi/anak usia 624 bulan rata-rata 10-15 bayi/anak.

\section{METODE PENELITIAN}

\section{Desain Penelitian:}

Penelitian ini dilakukan dalam bentuk deskripsi analitik dengan pendekatan cross sectional, yaitu di mana asupan MPASI dan pertumbuhan diukur dalam satu waktu kemudian diinterpretasikan hasilnya sesuai dengan kriteria penilaian. Subyek penelitian adalah ibu yang memiliki balita usia 6-24 bulan sebanyak 18 responden.

Teknik pengumpulan data pada penelitian ini adalah dengan mengukur BB dan $\mathrm{TB}$ bayi atau anak, dan memberi kuesioner kepada ibu atau pengasuh. Dianalisis secara statistik menggunakan program SPSS 17.0 for Windows dengan tingkat signifikansi 0,05 , dan taraf kepercayaan $95 \%$. 
Lokasi penelitian:

yaitu di Posyandu Wirastri Gamping Sleman.

\section{Populasi dan sampel:}

Populasi adalah ibu-ibu yang memiliki bayi/anak usia 6-24 bulan di posyandu Wirastri Gamping Sleman. Sampel diambil dengan metode consecutive sampling sejumlah 18 bayi/anak

Sumber data. Sumber data pada penelitian ini menggunakan data primer dan data sekunder. Data primer diperoleh dari hasil pengukuran $\mathrm{BB}, \mathrm{PB}$ dan pengisian kuesioner. Sementara untuk data sekunder diperoleh dari buku KIA untuk melihat tanggal lahir.

\section{Analisa Data}

1. Analisis univariat

Analisis univariat untuk menggambarkan pertumbuhan berdasarkan umur, berat badan, tinggi badan, lingkar kepala, lingkar lengan atas, $\mathrm{BB} / \mathrm{U}, \mathrm{TB} / \mathrm{U}, \mathrm{BB} / \mathrm{PB}$, dan menggambarkan perkembangan.

2. Analisis bivariat

Untuk menguji hubungan asupan MPASI dengan pertumbuhan bayi/anak usia 6-24 bulan menggunakan analisis uji statistik Chi Square dengan batas kemaknaan $\alpha=0,05$.

\section{HASIL PENELITIAN}

Penelitian ini dilakukan di Posyandu Wirastri Gamping Sleman pada bulan Oktober sampai dengan Desember 2018. Penelitian yang bertujuan untuk mengetahui hubungan pemberian asupan makanan pendamping ASI (MPASI) pada bayi/anak usia 6-24 tahun. Hasil tercantum pada tabel dibawah ini :

Tabel 1. Distribusi Frekuensi Status Gizi Pada Bayi/Anak Usia 6-24 Bulan

\begin{tabular}{lcccccc}
\hline Status & \multicolumn{2}{c}{ Baik } & \multicolumn{2}{c}{ Lebih } & \multicolumn{2}{c}{ Kurang } \\
Gizi & F & \% & F & \% & F & \% \\
\hline BB/U & 17 & 94,4 & 0 & 0 & 1 & 5,6 \\
\hline \multicolumn{3}{r}{ Berdasarkan } & tabel & 1 & diketahui
\end{tabular}

bahwa distribusi frekuensi status gizi pada bayi/anak usia 6-24 bulan berdasarakan BB/U mayoritas gizi baik 17 bayi/anak $(94,4 \%)$.

Tabel 2. Distribusi Frekuensi Pemberian ASI Eksklusif Pada Bayi/Anak Usia 6-24 bulan

\begin{tabular}{|c|c|c|c|}
\hline \multirow{2}{*}{$\begin{array}{l}\text { Komponen } \\
\text { MPASI }\end{array}$} & \multicolumn{2}{|c|}{$\begin{array}{cc}\text { Sesuai } & \text { Tidak } \\
\text { Standar } & \text { Sesuai }\end{array}$} & \multirow[t]{2}{*}{ Jumlah } \\
\hline & $\%$ & F \% & \\
\hline $\begin{array}{l}\text { Pemberian } \\
\text { ASI } \\
\text { Eksklusif }\end{array}$ & 1583,3 & 316,7 & 18 \\
\hline
\end{tabular}

Tabel 3. Distribusi Frekuensi Variasi Makanan Bayi/Anak Usia 6-24 Bulan

\begin{tabular}{|c|c|c|c|c|}
\hline \multirow{2}{*}{$\begin{array}{l}\text { Komponen } \\
\text { MPASI }\end{array}$} & \multicolumn{2}{|c|}{$\begin{array}{c}\text { Sesuai } \\
\text { Standar }\end{array}$} & $\begin{array}{l}\text { Tidak } \\
\text { Sesuai }\end{array}$ & \multirow[t]{2}{*}{ Jumlah } \\
\hline & $\mathbf{F}$ & $\%$ & $\%$ & \\
\hline Variasi & 14 & 77,8 & 422,2 & 18 \\
\hline \multicolumn{5}{|c|}{$\begin{array}{l}\text { Berdasarkan tabel } 3 \text { variasi makanan } \\
\text { bayi/anak usia } 6-24 \text { bulan mayoritas }\end{array}$} \\
\hline
\end{tabular}

Tabel 4. Distribusi Frekuensi Porsi Asupan Makanan Pendamping ASI Pada Bayi/Anak Usia 6-24 Bulan

\begin{tabular}{cccccc}
\hline \multirow{2}{*}{$\begin{array}{c}\text { Komponen } \\
\text { MPASI }\end{array}$} & \multicolumn{2}{c}{ Sesuai } & \multicolumn{3}{c}{ Tidak } \\
& F & \% & F & \% & \\
& Fesuai & Jumlah \\
\hline Frekuensi & 14 & 77,8 & 4 & 22,2 & 18 \\
\hline
\end{tabular}


Berdasarkan tabel 4 frekuensi porsi asupan makanan pendamping ASI mayoritas sesuai standar sebanyak 14 bayi/anak $(77,8 \%)$.

Tabel 5. Distribusi Frekuensi Porsi Asupan Makanan Pendamping ASI Pada Bayi/Anak Usia 6-24 Bulan

\begin{tabular}{lccccc}
\hline \multirow{2}{*}{$\begin{array}{c}\text { Komponen } \\
\text { MPASI }\end{array}$} & \multicolumn{2}{c}{ Sesuai } & \multicolumn{2}{c}{ Tidak } & \\
& F & \% & F & \% & \\
\hline $\begin{array}{l}\text { Porsi } \\
\text { Asupan }\end{array}$ & 15 & 83,3 & 3 & 16,7 & 18 \\
\hline
\end{tabular}

Berdasarkan tabel 5 distribusi frekuensi porsi asupan mayoritas sesuai standar sebanyak 15 bayi/anak $(83,3 \%)$.

Tabel 6. Distribusi Frekuensi Usaha Pengasuh Dalam Pemberian Asupan MPASI Pada Bayi/Anak Usia 6-24 Bulan

\begin{tabular}{lcrccc}
\hline \multicolumn{1}{c}{$\begin{array}{c}\text { Komponen } \\
\text { MPASI }\end{array}$} & \multicolumn{2}{c}{ Ada } & \multicolumn{2}{c}{ Tidak } & \\
& F & \% & F & \% & Jumlah \\
\hline $\begin{array}{l}\text { Usaha } \\
\text { Pengasuh }\end{array}$ & 18 & 100 & 0 & 0 & 18 \\
\hline
\end{tabular}

Berdasarkan tabel 6 distribusi frekuensi usaha pengasuh dalam pemberian asupan MPASI mayoritas ada usaha sebanyak 18 bayi/anak (100\%).

Tabel 7. Distribusi Frekuensi Pemberian Multivitamin Pada Bayi/Anak Usia 6-24 Bulan

\begin{tabular}{cccccc}
\hline \multirow{2}{*}{$\begin{array}{c}\text { Komponen } \\
\text { MPASI }\end{array}$} & \multicolumn{2}{c}{$\begin{array}{c}\text { Tidak } \\
\text { diberi }\end{array}$} & \multicolumn{2}{c}{ Diberi } & Jumlah \\
& F & $\%$ & F & $\%$ & \\
\hline Multivitamin & 18 & 100 & 0 & 0 & 18 \\
\hline \multicolumn{4}{c}{ Berdasarkan tabel } & 7 & distribusi \\
frekuensi & pemberian & \multicolumn{2}{c}{ multivitamin } \\
mayoritas tidak diberikan & multivitamin \\
sebanyak 18 bayi/anak $(100 \%)$.
\end{tabular}

Tabel 8. Distribusi Frekuensi Status Kesehatan Bayi/Anak Usia 6-24 Bulan

\begin{tabular}{|c|c|c|c|c|c|}
\hline \multirow{2}{*}{$\begin{array}{c}\text { Komponen } \\
\text { MPASI }\end{array}$} & \multicolumn{2}{|c|}{ Sehat } & \multicolumn{2}{|c|}{ Pemulihan } & \multirow{2}{*}{ Jumlah } \\
\hline & $\mathbf{F}$ & $\%$ & $\mathbf{F}$ & $\%$ & \\
\hline Status & 1 & 94, & & & \\
\hline Kesehatan & 7 & 4 & 1 & 5,6 & 18 \\
\hline
\end{tabular}

Tabel 9. Hubungan Asupan Makanan Pendamping ASI Dengan Pertumbuhan Pada Bayi/Anak Usia 6-24 Bulan

\begin{tabular}{|c|c|c|c|c|c|c|c|c|c|c|c|}
\hline \multirow[b]{2}{*}{$\begin{array}{c}\text { Pemberian } \\
\text { MPASI }\end{array}$} & \multirow[b]{2}{*}{ Tinggi } & \multirow[b]{2}{*}{$\%$} & \multicolumn{4}{|c|}{ PERTUMBUHAN (BB/U) } & \multirow[b]{2}{*}{$\begin{array}{l}\text { Sangat } \\
\text { Pendek }\end{array}$} & \multirow[b]{2}{*}{$\%$} & \multirow[b]{2}{*}{ Total } & \multirow[b]{2}{*}{$\%$} & \multirow[b]{2}{*}{$\begin{array}{c}P \\
\text { value }\end{array}$} \\
\hline & & & $\begin{array}{l}\text { Norm } \\
\text { al }\end{array}$ & $\%$ & Pendek & $\%$ & & & & & \\
\hline Baik & 0 & 0 & 10 & 55,5 & 0 & 0 & 2 & 11,1 & 12 & 66,6 & \\
\hline Cukup & 0 & 0 & 2 & 11,1 & 1 & 5,55 & 0 & 0 & 3 & 16,5 & 0,45 \\
\hline Kurang & 2 & 11,1 & 0 & 0 & 0 & 0 & 1 & 5,55 & 3 & 16,5 & \\
\hline \multicolumn{8}{|c|}{ Total } & & 18 & 100 & \\
\hline \begin{tabular}{l}
\multicolumn{2}{c}{ Berd } \\
bahwa re \\
MPASI \\
pertumbuh \\
responden \\
pemberian
\end{tabular} & $\begin{array}{l}\text { asarkan } \\
\text { sponden } \\
\text { baik } \\
\text { annya } \\
(55,5 \%), \\
\text { MPASI }\end{array}$ & $\begin{array}{r}\text { tabe } \\
\text { den } \\
\text { set } \\
\text { norm } \\
\text {, res } \\
\text { cukup }\end{array}$ & $\begin{array}{l}\text { gan p } \\
\text { agian } \\
\text { al ya } \\
\text { ponden } \\
\text { sebag }\end{array}$ & be & $\begin{array}{l}\text { per } \\
\text { res } \\
\text { pen } \\
\text { per } \\
\text { ana } \\
0,4\end{array}$ & $\begin{array}{l}\text { tumbu } \\
\text { oonde } \\
\text { aberia } \\
\text { tumbu } \\
\text { lisis } r \\
5>0,0\end{array}$ & $\begin{array}{l}\text { hannya } \\
(11,1 \% \\
\text { n MPAS } \\
\text { hannya }\end{array}$ & $\begin{array}{r}\text { no1 } \\
\text { dan } \\
\text { I kurc } \\
\text { tingg }\end{array}$ & $\begin{array}{l}\text { rmal } \\
\text { respon } \\
\text { ang seb } \\
\text { i }(11,1\end{array}$ & $\begin{array}{l}\text { yaitu } \\
\text { len de } \\
\text { gian } 1 \\
\% \text { ). }\end{array}$ & $\begin{array}{r}2 \\
\text { engan } \\
\text { besar } \\
\text { Hasil } \\
\text { value } \\
\text { ingan }\end{array}$ \\
\hline
\end{tabular}


yang signifikan antara pemberian MPASI dengan pertumbuhan bayi/balita usia 6-24 bulan di posyandu Wirastri Gamping Sleman.

\section{PEMBAHASAN}

Pada tabel 9 menunjukkan bahwa berdasarkan $\mathrm{BB} / \mathrm{U}$ bayi/anak dengan status normal sebagian besar memiliki pemberian makanan pendamping ASI (MPASI) kategori baik. Sedangkan untuk $\mathrm{BB} / \mathrm{U}$ bayi/anak dengan status tinggi adalah dengan pemberian makanan pendamping ASI (MPASI) dengan kategori kurang.

Uji statistik didapatkan $\mathrm{p}=0,45$ yang menunjukkan bahwa tidak terdapat hubungan antara pemberian MPASI dengan pertumbuhan bayi/anak usia 6-24 bulan berdasarkan status gizi indeks $\mathrm{BB} / \mathrm{U}$ di posyandu Wirastri Gamping Sleman. Hasil ini sesuai dengan hasil penelitian yang dilakukan oleh Herlistya dan Muniroh pada tahun 2015 yang diakukan di Surabaya yang menunjukkan tidak ada hubungan tidak terdapat hubungan antar pemberian Makanan Pendamping ASI (MPASI) dengan status gizi bayi umur 612 bulan berdasarkan status gizi bayi umur 6-12 buan berdasarkan status gizi indeks BB/U.

Pemberian makanan pada seorang bayi/anak harus memperhatikan baik dari segi kualitas maupun kuantitas yang adekuat pada setiap tahapnya. Selain ASI, bayi/anak membutuhkan makanan tambahan sebagai pendamping ASI karena ASI tidak bisa mencukupi kebutuhan gizi bayi/anak yang semakin meningkat. Makanan Pendamping ASI (MPASI) pada bayi/anak perlu memperhatikan frekuensi makan, bentuk/jenis makanan, dan makanan selingan sesuai dengan umur bayi.
Ibu-ibu yang memiliki bayi/anak usia 6-12 bulan di posyandu Wirastri sebagian besar adalah ibu rumah tangga sehingga ibu yang melakukan persiapan makanan sendiri dengan memasak setiap harinya. Ibu memberikan bayi/anak makanan bayi/anak tepat pada umur 6 bulan. Makanan Pendamping ASI (MPASI) yang diberikan oleh ibu sudah memenuhi kriteria bentuk/jenis yang tepat sesuai umur. Begitu juga dengan frekuensi pemberian makan pada bayi/anak yang diberikan ibu sudah tepat sesuai pertambahan umur bayi/anak. Untuk variasi makanan yang diberikan oleh ibu sudah baik termasuk pemberian buah dan makanan selingan yang tepat diberikan saat bayi/anak diatas 9 bulan dengan 2 kali pemberian. Sebagian besar ibu juga melakukan usaha agar anak mau makan dengan mengajak jalan atau bermain.

Makanan yang diberikan pada bayi hendaknya tepat baik dari jenis, jumlah hingga kandungan gizinya. Asupan gizi pada bayi hampir sama dengan orang dewasa yang hendaknya mengandung karbohidrat, protein, vitamin, lemak, dan vitamin.

\section{KESIMPULAN DAN SARAN}

Kesimpulan:

Hubungan asupan makanan pendamping ASI dengan pertumbuhan pada bayi/anak 6-24 bulan adalah tidak ada hubungan yang signifikan antara pemberian MPASI dengan pertumbuhan bayi/anak.

Saran:

1. Bagi Kader Posyandu

Memberikan informasi lengkap kepada ibu-ibu tentang makanan pendamping ASI (MPASI) agar pemberian makanan sesuai rekomendasi dan kebutuhan bayi/anak 
2. Bagi Ibu yang memiliki bayi/anak usia 6-24 bulan.

Diharapkan ibu-ibu dapat menggali informasi lebih dari tenaga kesehatan atau kader tentang pemberian makanan pendamping ASI (MPASI) sesuai kebutuhan bayi/anak dan rekomendasi 4 bintang serta cara pengolahan dan variasi pengolahan bahan-bahan makanan agar anak tidak bosan.

3. Peneliti Selanjutnya

Kepada peneliti selanjutnya dengan sampel yang lebih besar, serta memperhatikan faktor-faktor lain seperti penyakit infeksi, penyediaan makanan, dan pola asuh anak.

\section{DAFTAR RUJUKAN}

Achadi, Endang L. 2014. Periode Kritis 1000 Hari Pertama Kehidupan dan Dampak Jangka Panjang terhadap Kesehatan dan Fungsinya. Kursus Penyegar Ilmu Gizi: PERSAGI;.

Khomsan, Ali. 2007. Mengetahui Status Gizi Balita Anda. http://medicastore.com/artikel/247/i, diakses: 09/02/2015.

Depkes RI. 2006. Pedoman Umum Pemberian Makanan Pendamping Air Susu Ibu (MP ASI) Lokal. Jakarta: Depkes.

WHO. 2003. Global Strategy for Infant and Young Child. World Health Organization. Geneva.

Frongillo EA, Nguyen PH, Saha KK, Sanghvi T, Afsana K, Haque R, et al. Large-Scale Behavior-Change Initiative for Infant and Young Child Feeding Advanced Language and Motor Development in a ClusterRandomized Program Evaluation in Bangladesh. J Nutr. 2017;147(2):256-63.
Almatsier,S., Soetardjo, Susirah \& Soekatri, M. 2011.Gizi Seimbang Dalam Daur Kehidupan. Jakarta: Gramedia.

Istiany, A dan Rusilanti. 2014. Gizi Terapan. Bandung : PT Remaja Rosdakarya.

Marimbi, H.2010. Tumbuh Kembang Status Gizi, dan Imunisasi Dasar Balita.Yogyakarta : Nuha Medik. 